\title{
Assessment of Water Supply Services and Operational Performance of Asmara Water Supply Department (AWSD) for Development of Decision Support Tools
}

\author{
Kahsay N. Zeraebruk ${ }^{1}$, Alfred O. Mayabi ${ }^{1}$, John M. Gathenya ${ }^{1} \&$ Zemenfes Tsige $^{2}$ \\ ${ }^{1}$ College of Engineering and Technolgy, Jomo Kenyatta University of Agriculture and Technology, Kenya \\ ${ }^{2}$ National Board for Higher Education of Eritrea, former University of Asmara, Eritrea \\ Correspondence: Kahsay Zeraebruk, Department of Civil Construction and Environmental Engineering, JKUAT, \\ P.O. Box 62000-00200, Nairobi, Kenya. Tel: 254-708-725-239. E-mail: kahsayneg2000@gmail.com
}

\author{
Received: September 18, 2014 Accepted: October 4, 2014 Online Published: October 22, 2014 \\ doi:10.5539/enrr.v4n4p208 URL: http://dx.doi.org/10.5539/enrr.v4n4p208
}

\begin{abstract}
Achievement of Millennium Development Goals (MGDs) for water and sanitation requires significant investment, effective management, and participation of all stakeholders. This is especially highly challenging in low-income countries where utility inefficiencies due to limited infrastructure and absence of effective management system are still most prevalent. The problems of inadequate water and sanitation service provision in cities of developing countries are exacerbated by high growth rate in urban population. The proportion of the world's population that lives in urban areas has increased from $43 \%$ in 1990 to $50 \%$ in 2008 (UNICEF/WHO, 2011). Asmara is the capital of the state of Eritrea and the administrative centre of the Central Region, and Asmara Water Supply Department (AWSD) is the only public utility responsible for water and sanitation services in the city and surrounding areas. Similar to most public water utilities in sub-Saharan Africa, AWSD has been facing financial and technical constraints due to an inefficient management and operation systems resulting from lack of qualified personnel, low tariffs, high non-revenue water (NRW), over staffing, poor consumer records and inefficient billing and collection practices. The problems were further exacerbated by the limited available water resources, aging infrastructure, lack of human resource development program, and lack of an effective planning and management system. This study aims in building a system of performance measurement, monitoring and analysis, and benchmarking practices to promote development of decision support tools to improve the management and operational process of the utility. The analysis of selected performance indicators showed that the water services provided by the water utility were unsatisfactory due to various factors such as, low service coverage, intermittent mode of water distribution, long-period of cut-offs, and poor management and customer care services. The results of this study emphasize the urgency of wide-ranging reforms needed by the decision makers in Asmara in order to achieve effective, efficient and sustainable water supply system.
\end{abstract}

Keywords: performance indicators, benchmarking, water utility, AWSD, decision support system

\section{Introduction}

The sustainability of human development and economic growth is being threatened by the growing scarcity of water. Climate change is likely to worsen the situation. Water will increasingly dominate national and international politics.

Clean water and adequate sanitation are essential for health and well-being, unfortunately, poor governance of water and sanitation systems means that many periurban and rural areas lack services, and where they are available, the quality of service is unsatisfactory (Asís, Leary, Ljung, \& Butterworth, 2009). These problems are wide spread in many developing countries especially in Sub-Saharan Africa where the utilities lack efficient and transparent management system. Urban water resources should be pursued through robust management, integrated policy making, efficient resource allocation and utilization, and efficacious information collection and dissemination (Vaziri \& Tolouei, 2010). The principal challenge for Africa in the urban sphere is to address how its cities and towns respond to the massive challenges of rapid urbanization, urban expansion, increased demand for services, threats to water supply, constrained and failing urban planning systems, and institutional practices 
that work in isolation (Jacobsen, Webster, \& Vairavamoorthy, 2013). Without the presence of capable institutions, effective infrastructure, and policy frameworks to address the challenges, large numbers of households in urban areas in Africa will continue to have no or limited access to one of the most basic of human needs-a safe and reliable supply of drinking water.

The problems that account for urban water supply shortages in Sub-Saharan Africa are enormous and very complex in nature. These problems range from institutional bottlenecks like water utility management capacity and weak regulatory mechanisms to infrastructure problems such as poor urban planning, rapid growth of squatter communities, and insufficient financial resources (Ainuson, 2010). These had led to problems such as inadequate coverage, intermittent supply, inequitable water access, deteriorating infrastructure, high non-revenue water, and environmental unsustainability use of water. In African water utilities the reliability of service varies greatly as does the water consumption per capita, from 240 litres per capita per day in Johannesburg to 7 litres per capita per day in the Central African Republic(Jacobsen et al., 2013).

In order to improve the efficiency and quality of water services, service providers, regulators and decision makers should introduce appropriate management tools for measurement and monitoring of the performance of their water utilities. The managers of water utility should understand the importance of data collection, verification, storage, and processing to the success of the utility. The operator (water utility) public or private should be convinced that the task goes far beyond fulfilling a requirement of a financial statement where numbers are placed in particular columns, but also about how the data is useful for management (S. Berg \& Corton, 2007). According to S. Berg (2007) besides serving as a report to the regulator or to any external institution, data must be viewed as important and useful for the company - for strategic, operational, administrative and commercial purposes. There must be an understanding between the operator and the regulator on how the performance of the utility is evaluated through performance indicators and benchmarking. Comparisons with similar utilities elsewhere in the country or region or with standards of international good practice can shed light on how well a utility is performing, identify areas for improvement, and help indicate a plan of action (C. Van Den Berg \& Danilenko, 2011). Benchmarking is a powerful management tool that can be used for comparing one's business processes and performance metrics with the industry's best and/or best practices. It is usually used by water utility managers, policy makers, regulators and financial institutions for different purposes with the target of improving water services and optimizing operations (Makaya \& Hensel, 2014). If applied systematically, it is a powerful tool that results in resource savings for the company concerned with performance and it becomes vital for achieving efficiency improvement. A major challenge for measuring, and eventually benchmarking, water and wastewater utility performance has been the lack of standardized information (C. Van Den Berg \& Danilenko, 2011). Lack of reliable data and information is the main stumbling block in developing countries especially in Africa. Given the renewed focus on achieving the MDG targets for water and sanitation access on the continent, the evolving Water Operators Partnership-Africa program is well placed to connect utilities and facilitate knowledge sharing and capacity building - especially on improving technical efficiency and improving cash flows, areas that are critical to improving service coverage (WSP-Africa, 2009).

Continuing the public or private financing of the sector without significant efficiency improvement is a major waste of scarce resources in Africa (Estache \& Kouassi, 2002). Efficiency improvement can be achieved only if the service performance of the water utility can be evaluated against a standard set of performance indicators and targets. Efficiency savings exceeds revenue from user fees which implies that average tariff levels continue to be too high as compared to what they would be if firms were operated efficiently (Estache \& Kouassi, 2002). Performance assessment and benchmarking are powerful tools to make service providers more accountable, efficient and to measure progress while improving performance.

Eritrea is one of the developing countries, in Sub-Saharan Africa, facing most of the common challenges in providing water services to its citizens. The country is semi-arid and is not endowed with rich water recourses. It is categorised as a nation under water stress (less than $1000 \mathrm{~m} 3 /$ percapita/per annum) and the natural availability of water across the country is variable, and rainfall displays strong seasonality. Stream flow in Eritrean rivers is absent or is very low for most of the year except during the short rainy months. This feature limits the proportion of stream flow that can be relied upon for use for different purposes.

Asmara is the capital of the state of Eritrea and the administrative centre of the Central Region known as Administration of Maekel Zone (AMZ). Asmara Water Supply Department (AWSD) is the only public utility responsible for water and sanitation services in the city and surrounding areas. The public water supply system, in Asmara, has been seen to provide unsatisfactory services due to a combination of various reasons such as, low service coverage, intermittent mode of water distribution, and long period of cut-offs. The problems were related 
to limited and scarce water sources, aging infrastructure and substantial leakage losses, lack of human resource development program, and inefficient system of planning and management. The city has also expanded in recent years and as a result thirteen villages around Asmara became part of the city relying for water services on AWSD, creating yet additional stress to the water supply system in dealing with increasing demand for water.

This study had been initiated by the existence of information gap and little or no studies on the performance of public water supply utilities in Eritrea and the prevailing critical water supply situation in Asmara and its surrounding areas. The main objective of this study is to assess the level of technical and financial management and efficiency of the water utility in Asmara through systematically selected performance indicators in order to generate information to be used as a tool for making sound decisions and interventions for improvement of the quality of water services. The research seeks to use existing theories and tools to study major performance aspects of AWSD and also to assess the public perception on the performance of water services delivery in Asmara.

\section{Description of the Study Area}

The study area is based on the case study of Asmara water supply system. Asmara is the capital of the state of Eritrea and the administrative centre of the Central Region known as Administration of Maekel Zone (AMZ). Asmara is located at an average elevation of $2350 \mathrm{~m}$ above mean sea level in the central highlands of Eritrea (see Figure 1).

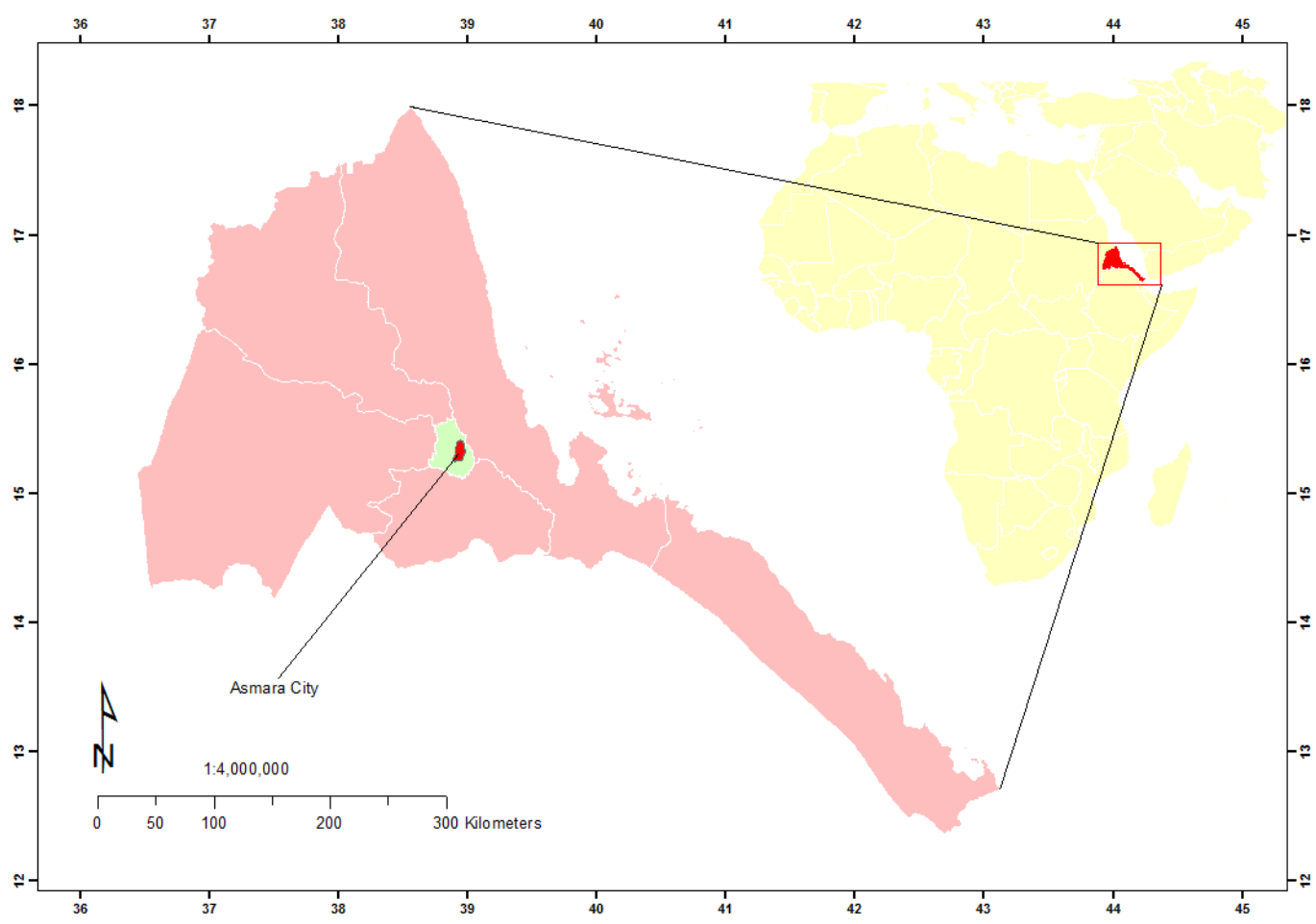

Figure 1. Location of the study area (Asmara city)

As a capital city and major business centre, Asmara has been growing relatively faster in recent years in surface area and population. Records indicate that the current population of Asmara, including the satellite villages, to be around 450,000 (Database of AMZ, 2012). Asmara Water Supply and Sewerage Department (AWSD) is the only public utility responsible for water and sewerage services in and around Asmara.

Systematic development of water supply and management in Eritrea dates back to the colonial times. The Italian colonial administration developed domestic water supply as part of overall programme to improve the level of personal hygiene and environmental sanitation in the major towns of Eritrea, especially in the capital city, Asmara. This is evident as some of the water supply infrastructure facilities currently in use for supplying water to the capital were built during the colonial period.

The major source of water supply for Asmara and the surrounding villages is surface water from rainfall collected during the rainy months of summer. The runoff created from the rainfall over the drainage areas joins 
streams and rivers and finally collected into dam reservoirs located around the city. The Toker, Adi-Sheka, and Mai-Sirwa reservoirs are located in the catchment areas north of the city. These rivers are tributaries of Anseba River which flows towards the north. The Mai Nefhi dam is located south west of the city and drains the catchment areas south of the city which are mostly tributaries of the Barka River.

Since independence in May 1991, the Government of the State of Eritrea has allocated substantial amount of capital budget for infrastructure development to improve provision of water services in Asmara. Efforts were also made by the water utility to improve service coverage by replacing old pipe lines and maintaining treatment plants and pumping stations. Nevertheless, the current water supply distribution services, and the management and operation system are inadequate, unreliable and inefficient to cope up with the demand.

The current water distribution conditions in Asmara and the surrounding villages are constrained due to several problems attributed to low technical and financial performance of the water utility. It is in this context that this study was initiated to establish the quality of water service delivery in Asmara in terms of set of standard performance indicators. The study focuses on the process of building systems for performance measurement, monitoring and analysis, and setting benchmarking as an integral part of operational practice of the utility.

\section{Research Problem}

As a public utility responsible for water and sanitation services in Asmara and its environs, AWSD is providing inadequate services to its customers. These include low service coverage and intermittent mode of water distribution characterised by long period of cut-offs and frequent water restrictions. The problems could be attributed to limited or scarce water sources, substantial rate of NRW, inadequate hydraulic capacity and aging water distribution infrastructure, coupled with technical incompetence and inefficient management. The consequences of poor water and sanitation services in terms of health and financial costs especially to the low-income households could be enormous and could affect national economic development.

Facing with the challenges of limited resources and also due to increasing demand for water, there is a need to establish how AWSD has been performing against a set of standard and internationally accepted key performance indicators. The systematic investigation will help to establish the position of AWSD in terms of its technical, financial and management capacity and develop mechanisms to improve the overall capacity of the utility to deliver better services to its customers. Moreover, the perception of residents regarding the quality of service delivery by AWSD needs to be established as there is no as such a regulatory body to protect the interests of consumers.

\section{Objectives of the Study}

The main objective of the study was to establish performance of AWSD in terms of technical, financial and customer care services against widely accepted key standard performance indicators and benchmarking the water utility against other well performing utilities around east Africa for purposes of development of decision support tools for better management of the system.

The specific objectives are

- To make an inventory of the service delivery indicators applicable for AWSD in order to determine its level of technical and financial performances.

- To conduct benchmarking assessment of AWSD's performance against one of the well performing utilities in east Africa namely Kampala Water which is the largest water supply branch under the National Water and Sewerage Corporation (NWSC) of Uganda.

- To provide decision makers and the management with information and decision support tools for improvement of service delivery.

\section{Methodology}

\subsection{Research Design and Data Collection}

This research was based on a case study approach. AWSD, which is the only service provider for water and sanitation in and around Asmara, was used as a case study to carry out investigation on performance of water services. The case study is preferred in examining contemporary events, but when the relevant behaviours cannot be manipulated (Yin, 1984). Further Yin (1984) reiterated that although the case study approach relies on many of the same techniques as a history, the advantage of case study approach is that it adds two sources of evidence not usually included in the historian's repertoire: direct observation and systematic interviewing and the case study's unique strength is its ability to deal with a full variety of evidence---documents, artefacts, interviews, and observations-beyond what might be available in the conventional historical study. 
This research sought to use existing theories and tools to study technical, operational, and financial performance of AWSD. The water utility (AWSD) and its customers were used as the main source of data and information. Semi-structured questionnaires were used to interview key staff and customers on the general performance of the utility. Data was also obtained from annual reports, project study reports, and related documents. Field observations by the research team assessed the condition of the water supply system including the management and operation system of AWSD. The research team also made field visits to NWSC mainly Kampala Water to observe the management process and operation procedures of the public utility.

The first step of the research design involved examining existing data and carrying out a preliminary survey to establish indicators which had an impact on Asmara's water service delivery. An inventory of the indicators specific for Asmara was therefore created from literature reviewing, interviews and survey data. In this case, four general performance categories were selected, namely: Technical performance, financial performance, customer care and quality of service, and human resources development and capacity building.

The next step adopted, as part of the methodology, was dividing each performance category into corresponding one or more appropriate performance indicators applicable for AWSD including expected performance targets in line with international standards based on the Africa Utility Performance Assessment issued in 2009 by Water Operators Partnerships-Africa (WSP-Africa, 2009). The performance categories and the corresponding performance indicators are shown in Table 1.

Table 1. List of performance indicators selected to evaluate the quality of service delivery by AWSD for Asmara Water Supply System

\begin{tabular}{|c|c|c|c|}
\hline Category & Performance Indicator and unit & Description & $\begin{array}{c}\text { Expected } \\
\text { benchmarking } \\
\text { target }\end{array}$ \\
\hline \multirow{5}{*}{$\begin{array}{l}\text { 1.Technical } \\
\text { Performance }\end{array}$} & 1.1 Water coverage $(\%)$ & Percentage of households connected to WDS & $90 \%$ \\
\hline & $\begin{array}{l}1.2 \text { Water production } \\
\text { (litres/person/day) }\end{array}$ & $\begin{array}{l}\text { Total annual water supplied to the WDS expressed } \\
\text { by population served per day }\end{array}$ & Variable \\
\hline & $\begin{array}{l}\text { 1.3 Water consumption } \\
\text { (litres/person/day) }\end{array}$ & $\begin{array}{l}\text { Average annual water consumed from WDS } \\
\text { expressed by population served per day }\end{array}$ & 76 l/c/d \\
\hline & 1.4 Metering level $(\%)$ & $\begin{array}{l}\text { Total number of connections with operating } \\
\text { meter/total number of connections }\end{array}$ & $100 \%$ \\
\hline & 1.5 Non-Revenue Water (\%) & $\begin{array}{l}\text { Difference between water supplied and water sold } \\
\text { expressed as a percentage of net water supplied }\end{array}$ & $25 \%$ \\
\hline \multirow[t]{4}{*}{$\begin{array}{l}\text { 2. Financial } \\
\text { Performance }\end{array}$} & $\begin{array}{l}2.1 \text { Average revenue of water } \\
\text { (US } \$ / \mathrm{m}^{3} \text { water sold) }\end{array}$ & $\begin{array}{l}\text { Operating revenues expressed by annual amount of } \\
\text { water sold. }\end{array}$ & - \\
\hline & $\begin{array}{l}2.2 \text { Average revenue of water } \\
\text { (US\$/water conn/yr) }\end{array}$ & $\begin{array}{l}\text { Total annual water operating revenues expressed by } \\
\text { the number of connections. }\end{array}$ & - \\
\hline & $\begin{array}{l}\text { 2.3 Unit operational cost of water } \\
\text { (US } \$ / \mathrm{m}^{3} \text { produced) }\end{array}$ & $\begin{array}{l}\text { Total annual operational expenses /total annual } \\
\text { water produced }\end{array}$ & - \\
\hline & 2.4 Operating cost coverage (ratio) & $\begin{array}{l}\text { Total annual operational revenues/total annual } \\
\text { operating costs }\end{array}$ & 1.2 \\
\hline \multirow{2}{*}{$\begin{array}{l}\text { 3. Customer } \\
\text { care and } \\
\text { quality of } \\
\text { Service }\end{array}$} & 3.1 Continuity of service (hours/day) & Average hours of service per day for water supply & 24 Hours \\
\hline & $\begin{array}{l}3.2 \text { No. of complaints/ } 1000 \\
\text { connections }\end{array}$ & $\begin{array}{l}\text { Average number of customer complaints per } 1000 \\
\text { connections }\end{array}$ & Variable \\
\hline \multirow{3}{*}{$\begin{array}{l}\text { 4. Human } \\
\text { Resources } \\
\text { Utilisation \& } \\
\text { Development }\end{array}$} & $\begin{array}{l}\text { 4.1 Staff } / 1,000 \text { Water connections } \\
(\# / 1,000 \text { water conn })\end{array}$ & $\begin{array}{l}\text { Total number of staff expressed as per thousand } \\
\text { Connections }\end{array}$ & $\begin{array}{l}7 \text { staff } / 1000 \\
\text { water } \\
\text { connection }\end{array}$ \\
\hline & $\begin{array}{l}\text { 4.2 Labour cost Vs operational costs } \\
(\%)\end{array}$ & $\begin{array}{l}\text { Total annual labour costs (including benefits) } \\
\text { expressed as a percentage of total annual } \\
\text { operational costs }\end{array}$ & $23 \%$ \\
\hline & $\begin{array}{l}\text { 4.3 Staff Training Participation Rate } \\
(\%)\end{array}$ & Percentage of the staff participated in training & $30 \%$ \\
\hline
\end{tabular}




\subsection{Data Analysis and Presentation}

Simple statistical analysis and mathematical computations were conducted and the results were presented in graphical and tabular formats. For each of the performance indicators the expected performance targets were set and the level of quality of water services delivered by AWSD were evaluated to support the water utility to make informed decisions to improve its efficiency and service quality.

\section{Results and Discussion}

\subsection{Technical Performance}

The technical performance of a water utility is closely related to the availability of water, capacity and condition of the infrastructure for production and distribution, and the system of operation and maintenance. It measures the performance of a water utility in terms coverage, water production and water consumption, metering level and Non-Revenue Water.

\subsubsection{Service Coverage (Percentage of Households Connected to the Water Supply Network)}

It is defined as the percentage of the population with access to water or services (either with direct service connection or within reach of a public water point) as a percentage of the total population under a utility's area of responsibility. The benchmarking target expected for water coverage is $80 \%$. Analysis of the data collected from the database of the AWSD shows that the current service coverage in terms of the population served from the distribution system is about $76 \%$.

Table 2. Percentage of households connected to the water supply network

\begin{tabular}{lcccccccc}
\hline \multicolumn{1}{c}{ Year } & 2005 & 2006 & 2007 & 2008 & 2009 & 2010 & 2011 & 2012 \\
\hline Target population & 420,000 & 420,000 & 420,000 & 450,000 & 450,000 & 450,000 & 450,000 & 450,000 \\
Population served & 276,400 & 284,050 & 290,800 & 308,350 & 317,395 & 328,852 & 329,878 & 347,210 \\
Water Coverage (\%) & 66 & 68 & 69 & 69 & 71 & 73 & 73 & 77 \\
\hline
\end{tabular}

As part of this study, the survey carried out in 2013 by direct interview of customers indicates the overall connection level (water service coverage) in Asmara was 78\% (Zeraebruk, Mayabi, Gathenya, \& Zemenfes, 2014). The primary source of water for the residents living in the areas without network connection was mainly water tankers. This indicator can provide valuable information on the performance of a utility if there is continuous supply of water in the distribution system. In other words, being connected does not mean the customer is guaranteed to adequate supply of water, which is true for the case of Asmara where many areas that are connected to WDS yet could only get water for few hours of the day on weekly or monthly basis.

For the case of Kampala Water the service coverage has shown remarkable improvement increasing from $58 \%$ in 2002 to $76 \%$ in 2011 .

\subsubsection{Water Production}

The water production has been evaluated as a total annual water supplied to the water distribution system (WDS) expressed by population served per day.

The source of water for municipal use for Asmara and the villages around the city is surface water collected by dam reservoirs. Based on the location of the reservoirs, the raw water is treated by three water treatment plants (WTP) namely StrettaVaudetto, Adinfas and Mainefhi treatment plants.

The design maximum treatment capacity for Toker, StrettaVaudetto and Mai Nefhi was $18,000,8,000$ and $18,000 \mathrm{~m}^{3} / \mathrm{d}$ respectively with the total production capacity of $44,000 \mathrm{~m}^{3} /$ day. However, data collected from past records and field visits to the treatment plants indicated that the average daily production was around $50 \%$ of the maximum capacity attributed to technical problems, aging infrastructure and at times to limited volume of water in storage reservoirs.

There was no systematic measurement and recording of data on water produced and pumped by the treatment plants which could ensure adequate control and consistency. The production rate was estimated on the basis of data partly coming from some macro meters and partly extrapolated from indirect observations, such as working pumping hours and nominal features and hydraulic rating of pumps. As a result of insufficient data, there are only estimates of the annual production rates as shown in Table 3. 
Table 3. Annual and average daily water production

\begin{tabular}{|c|c|c|c|c|c|c|c|c|}
\hline Year & 2005 & 2006 & 2007 & 2008 & 2009 & 2010 & 2011 & 2012 \\
\hline $\begin{array}{l}\text { Annual Water production } \\
\mathrm{m}^{3}\left(\mathrm{x} 10^{6}\right)^{*}\end{array}$ & 6.43 & - & 8.49 & 9.05 & 7.47 & 7.60 & 9.62 & 7.46 \\
\hline Average daily production ( $\mathrm{m}^{3} /$ day $)$ & 17,616 & - & 23,260 & 24,795 & 20,466 & 20,822 & 26,356 & 20,438 \\
\hline $\begin{array}{l}\text { Average water production } \\
\text { (litres/person/day) }\end{array}$ & 39 & - & 52 & 55 & 41 & 42 & 53 & 41 \\
\hline
\end{tabular}

*Source: AWSD Annual reports.

The information obtained from annual reports of NWSC of Uganda for 2011 indicated that the annual average water production in Kampala Water was estimated around 110 litres per capita per day $(\mathrm{l} / \mathrm{c} / \mathrm{d})$.

\subsubsection{Water Consumption}

As a performance indicator the water consumption is analysed as average annual water consumed from WDS expressed by volume per population served per day.

In the case of AWSD, it was not possible to get the monthly or annual water consumption from the bills. First of all the database was not developed and maintained properly. Secondly the billing is produced not on the basis of the amount of water consumed rather on the minimum amount of water each customer was expected to use, which is $10 \mathrm{~m}^{3} /$ month for domestic customers. Domestic customers who consumed less than the minimum volume would pay their bills as if they had consumed the minimum amount. Even customers connected to the system but without running water for many weeks and months are obliged to pay their bills based on the expected minimum consumption. Measurement or estimation accurately the volume of water sold to customers is the most valuable data and performance indicator that any water utility should have. Such information is important for managers and decision makers to promote appropriate changes in the operation and management of their utility to achieve efficiency by controlling losses.

As part of this study, the analysis of the survey data carried out on 300 households (customers) randomly selected throughout the city, showed that the average daily water consumption was about $23 \mathrm{l} / \mathrm{c} / \mathrm{d}$ (Table 4 ). For Kampala Water the average daily consumption in 2011 was about $67 \mathrm{l} / \mathrm{c} / \mathrm{d}$. If a $50 \mathrm{l} / \mathrm{c} / \mathrm{d}$ was taken as the minimum amount needed for healthy living, it is evident that the majority of the people in Asmara have been getting water below the minimum amount required (Zeraebruk et al., 2014).

Table 4. Summary of daily water consumption

\begin{tabular}{lccccc}
\hline & \multicolumn{5}{c}{ Water Consumption ( 1/c/d) } \\
\cline { 2 - 6 } Percentage of households & $10-15$ & $15-20$ & $20-25$ & $25-30$ & 30 and above \\
\cline { 2 - 6 } & $11 \%$ & $44 \%$ & $28 \%$ & $5 \%$ & $12 \%$ \\
\hline
\end{tabular}

\subsubsection{Metering Level}

The metering of customers is considered a good practice because it allows customers to influence their water bills and provides utilities with tools and information to allow them to better manage their systems and improve service delivery.As performance indicator the metering level has been expressed as a ratio of the number of connections with operating meter to total number of connections.

AWSD applies the rule of universal metering. Customers connected to the water distribution system should own water meters registered to a single household. Nevertheless, it is possible for one water meter to be shared by two or more households residing in the same compound.

Although as a performance indicator the level of metering for AWSD could be assumed close to $100 \%$, the critical issue is the reliability and accuracy of the meters. Metering errors and meter ageing are partly responsible for apparent water losses and thus have a negative impact on the economic balance of the water manager (Fontanazza, Freni, \& Loggia, 2012). To minimize the loss of revenue due to defective water meters, water utilities need to have systematic water meter maintenance and replacement programmes. 
AWSD has no database that can be relied upon to get accurate information about the type and condition of the existing meters. This study showed that the majority of the customers' complaints in AWSD were related to the working condition of water meters because most of them are not functioning properly due to ageing and/or blockage with silt. Table 5 gives some information on the services provided by ASWD technical unit in meter repair and replacement.

Table5. Number of customers with water meters and annual water meters repair and replacement

\begin{tabular}{ccccccccccc}
\hline \multicolumn{1}{c}{ Year } & 2001 & 2002 & 2003 & 2004 & 2005 & 2006 & 2007 & 2008 & 2009 & 2010 \\
\hline Number customers & 24,750 & 26,100 & 27,200 & 27,500 & 28,300 & 29,150 & 29,900 & 31,850 & 32,855 & 34,128 \\
Water meters replaced & 70 & 1006 & 1020 & 1038 & 1116 & 1080 & 337 & 695 & 389 & 109 \\
Water meters repaired & 74 & 67 & 81 & 56 & 47 & 13 & 19 & 15 & 17 & 7 \\
\hline
\end{tabular}

\subsubsection{Non-Revenue Water (NRW)}

NRW is defined as the difference between water supplied and water sold (i.e. volume of water 'lost') expressed as a percentage of net water supplied. NRW represents water that has been produced and is 'lost' before it reaches the customer (either through leaks, theft or through legal usage for which no payment is made). This indicator captures not only physical losses but also commercial losses due to inefficient billing or illegal connections. Thus high levels of NRW may indicate poor system management and poor commercial practices as well as inadequate network maintenance.

Although very important parameter of performance, as regards to AWSD there was no accurate measured data readily available to estimate the amount of water lost due to leakage or other causes. At the same time there is no strategy or action plan to identify leakages and control water losses.

Without up-to-date customer databases to ensure that all users are being billed correctly, and without comprehensive measurement of production and consumption, data on NRW are, at best, indicative. Technical reports prepared by consultants estimated that the rate of NRW in Asmara water supply system to be around $40 \%$ when the whole network is continuously under pressure. Considering the scarcity of water resources in the area and the rate of water production, the NRW was very high indicating the inefficient performance of the system. Figure 2 shows the annual water production obtained by review of AWSD documentation and the annual water billed calculated based on $40 \%$ of NRW. AWSD must make urgent intervention in its management and operation system to control and reduce the huge loss of treated water due to NRW.

Despite all the many success stories in the operation and management of NWSC of Uganda, the NRW still remains to be higher than the recommended benchmarking target of $25 \%$. From the reports it was found that NRW for Kampala Water was 40.6\% in 2005 (NWSC, 2005) and 39.2\% in 2011 (NWSC, 2011).

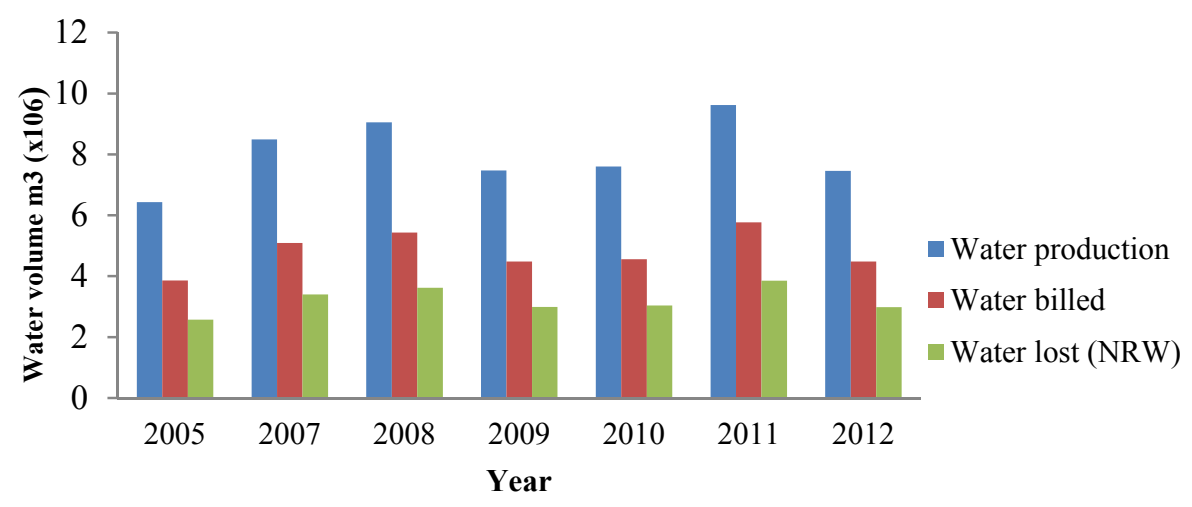

Figure 2. ASWD water production and water billed (with $40 \%$ NRW) 


\subsection{Financial Performance}

Financial sustainability of a water utility is determinant of the provision of reliable and safe water supply. Financial discipline in the sector allows water utilities to produce cash surplus which is vital for meeting new investment requirements and for responding to maintenance and rehabilitation needs. Weak financial management systems can pose risks to sector viability and sustainability. Structuring pricing to meet social, economic, and technical objectives, promoting financial efficiency through strengthening the billing and collection systems, and enforcing accountability are very important aspects for improvement of the overall performance and sustainability of services.

The financial performance indicators give insight into the financial discipline of a utility, its ability to cover operational costs with revenues from tariffs, and the general commitment to pursue a commercial approach to the provision of a public service.

Table 6. Summary of Annual Revenue and Expenditure (millions Nakfa)

\begin{tabular}{cccccccccc}
\hline Financial year & 2004 & 2005 & 2006 & 2007 & 2008 & 2009 & 2010 & 2011 & 2012 \\
\hline Revenue (millions of Nakfa $*$ ) & 41.2 & 52.2 & 49.6 & 55.1 & 49.9 & 64.0 & 17.6 & 67.57 & 46.37 \\
Expenses (millions of Nakfa $*$ ) & 37.2 & 43.5 & 53.2 & 37.9 & 35.2 & 57.2 & 41.7 & 41.7 & 53.6 \\
\hline
\end{tabular}

*1 USD=15.5 Nakfa (Official exchange rate).

\subsubsection{Average Revenue of Water (US\$ $/ \mathrm{m}^{3}$ Water Sold)}

This is calculated as the ratio of a utility's total annual direct billed revenue to the total annual water consumption (that is, volume of water sold).

In the case AWSD, it is not easy to directly find the average tariff per $\mathrm{m}^{3}$ sold due to the following reasons:

- Data on how much of the treated water has been used by customers and billed is not readily available from the database. In other words the NRW is not readily available.

- There are differences between the volume of water indicated on their bills and the actual amount of water consumed because the bills are produced based on the minimum amount of water customers were supposed to use, which is $10 \mathrm{~m}^{3}$ of water for domestic use.

Customers with connection who did not get water for several months are obliged to pay their bills calculated on the basis of the minimum amount of water they were supposed to use. Such customers have to settle their bills as if they have consumed the minimum amount of water. Since the water rationing system introduced so many customers are consuming much less than the stipulated minimum amount which at the end of the day exaggerates the total volume of water sold by the utility.

Table 7. Average annual revenue of water (revenue/ $\mathrm{m}^{3}$ water sold)

\begin{tabular}{|c|c|c|c|c|c|c|c|c|}
\hline Year & 2005 & 2006 & 2007 & 2008 & 2009 & 2010 & 2011 & 2012 \\
\hline Water production $\mathrm{m}^{3}\left(\mathrm{x} 10^{6}\right)^{*}$ & 6.43 & - & 8.49 & 9.05 & 7.47 & 7.60 & 9.62 & 7.46 \\
\hline $\begin{array}{l}\text { Average revenue of water } \\
\left(\mathrm{Nakfa} / \mathrm{m}^{3} \text { water sold }\right)^{* *}\end{array}$ & 13.53 & - & 10.82 & 9.18 & 14.28 & 4.11 & 10.12 & 10.09 \\
\hline $\begin{array}{l}\text { Average revenue of water } \\
\left(\mathrm{US} \$ \mathrm{~m}^{3} \text { water sold }\right)^{* * *}\end{array}$ & 0.87 & - & 0.70 & 0.59 & 0.92 & 0.27 & 0.65 & 0.65 \\
\hline
\end{tabular}

*Source: AWSD Annual reports, ** Assuming 40\% Non-revenue water, *** 1US\$=15.5 Nakfa (Eritrean currency).

The average revenue of water for Asmara was not very far from that of Kampala Water which was $0.39 \mathrm{US} \$ / \mathrm{m}^{3}$ water sold in 2005 and $0.72 \mathrm{U} \$ / \mathrm{m}^{3}$ water sold in 2011.

\subsubsection{Average Revenue of Water (US\$/water conn/yr)}

This is calculated as the ratio of a utility's total annual water operating revenues expressed by the number of connections. The performance indicator provides financial efficiency of the utility in terms of the number of customers benefiting from its services. 
Table 8. Total annual water operating revenues revenue/connection

\begin{tabular}{lcccccccc}
\hline \multicolumn{1}{c}{ Year } & 2005 & 2006 & 2007 & 2008 & 2009 & 2010 & 2011 & 2012 \\
\hline Water revenue Nakfa $\left(\mathrm{x} 10^{6}\right)$ & 52.19 & 49.65 & 55.12 & 49.87 & 64.00 & 17.56 & 67.47 & 46.27 \\
Number of Customers & 28,300 & 29,150 & 29,900 & 31,850 & 32,855 & 34,128 & 34,128 & 34,721 \\
Revenue (Nakfa/water conn/yr) & $1,844.29$ & $1,703.21$ & $1,843.37$ & $1,565.64$ & $1,947.98$ & 514.50 & $1,976.85$ & $1,332.56$ \\
Revenue (US\$/water conn/yr) & 118.99 & 109.88 & 118.93 & 101.01 & 125.68 & 33.19 & 127.54 & 85.97 \\
\hline
\end{tabular}

For Kampala Water the annual revenue per connection was estimated US\$ 190 in 2005 and US\$ 224 in 2011. As shown in the Table 8, the average annual revenue per connection in AWSD is around 103 US\$/connection which is very low as compared to Kampala Water.

\subsubsection{Unit Operational Cost of Water (US $\$ / \mathrm{m}^{3}$ Produced)}

As a performance indicator the unit operational cost of water provides the effectiveness of the utility in terms of the operating cost needed to produce a unit volume of water. It is a very important parameter because it provides an insight to the productivity of the utility.

Table 9. Annual Unit Operational Cost of Water

\begin{tabular}{lrrrrrrrrr}
\hline \multicolumn{1}{c}{ Year } & 2005 & 2006 & 2007 & 2008 & 2009 & 2010 & 2011 & 2012 & Average \\
\hline Water production $\mathrm{m}^{3}\left(\mathrm{x} 10^{6}\right)$ & 6.43 & - & 8.49 & 9.05 & 7.47 & 7.60 & 9.62 & 7.46 & 8.02 \\
Total Operation cost $\left(\mathrm{Nakfax} 10^{6}\right)$ & 42.90 & 37.54 & 36.80 & 34.95 & 57.03 & 17.24 & 38.96 & 47.27 & 39.09 \\
$\begin{array}{l}\text { Unit operational cost of water }\left(\mathrm{Nakfa} / \mathrm{m}^{3}\right. \\
\text { produced) }\end{array}$ & 6.67 & - & 4.34 & 3.86 & 7.63 & 2.27 & 4.05 & 6.34 & 5.02 \\
Unit operational cost of water (US $\$ \mathrm{~m}^{3}$ produced) & 0.43 & - & 0.28 & 0.25 & 0.49 & 0.15 & 0.26 & 0.41 & 0.32 \\
\hline
\end{tabular}

The analysis of the data showed that the unit operational cost of water in AWSD is around $0.32 \mathrm{US} \$ / \mathrm{m}^{3}$ of water produced. The operational cost of production of water in AWSD is in the lower side when compared to Kampala Water which was around US\$0.58 in 2011. In order to make a thorough analysis between Asmara and Kampala regarding this parameter additional information on cost of energy, salary scale and other expenses should be known.

\subsubsection{Operating Cost Coverage (Ratio)}

The operating cost coverage is the ratio between the total annual revenues and total annual operating costs. This performance indicator provides an insight to the capacity of the water utility to cover its operating costs and its margin of profit.

In the case of Asmara as shown in Table 10 the calculated operating cost coverage ratio looks good because it is close to 1.2 (expected benchmarking target). Nevertheless, the parameter may not provide the right information because of the bill preparation system based on the minimum amount of water each customer was supposed to consume. Customers without getting water from the system for many weeks had to pay the full amount based on the minimum consumption which $10 \mathrm{~m}^{3} /$ month for domestic customer.

Table 10. Operating cost coverage ratio

\begin{tabular}{cccccccccc}
\hline Year & 2005 & 2006 & 2007 & 2008 & 2009 & 2010 & 2011 & 2012 & Average \\
\hline Revenue (millions of Nakfa*) & 52.2 & 49.6 & 55.1 & 49.9 & 64 & 17.6 & 67.57 & 46.37 & 50.29 \\
Total operation cost (Nakfax10 ${ }^{6}$ ) & 42.9 & 37.54 & 36.8 & 34.95 & 57.03 & 17.24 & 38.96 & 47.27 & 39.09 \\
Operating cost coverage (ratio) & 1.22 & 1.32 & 1.50 & 1.43 & 1.12 & 1.02 & 1.73 & 0.98 & 1.29 \\
\hline
\end{tabular}

The recommended benchmarking target for operating cost coverage is 1.2 and it was 1.54 for Kampala Water in 2005 and 1.67 in 2011. Compared to Asmara Kampala is performing very well in this regard especially if the operating cost for salaries and allowances has been considered, which is much lower in Asmara. 


\subsection{Customer Care and Quality of Service}

There are a number of performance indicators that can be used to evaluate the quality of the services and levels of customer care delivered by a water utility. Some of the widely used PI include: Continuity of services in hours per day and number of complaints.

\subsubsection{Continuity of Service (Average Hours of Service per Day for Water Supply)}

In order to manage the shortage of water, since 2003 AWSD has introduced a rationing water distribution system applicable on weekly schedule by operating gate valves within the network. As a result, water is available for two to three days a week and for few hours of the day. Only small areas located along the route of the primary pipe line could get continuously water services. On the contrary, many areas which are located at the periphery of the distribution system or at high ground level experienced lack of water for several weeks and even months.

Due to the rationing distribution system, and lack of measured data and information it becomes difficult to analyse the continuity of services delivered by AWSD in terms of hours per day.

The analysis of the data collected through structured interview of customers showed that out of the households who expressed that the WDN as their primary source of water, $9 \%$ get water daily, $45 \%$ weekly and $46 \%$ monthly. In addition, the availability of water for customers who were in the weekly or monthly rationing category was between 1 to 3 days and for a maximum of 12 hours per day(Zeraebruk et al., 2014).

There was a clear indication that the rationing system of water distribution adopted by AWSD as a means of sharing water was not equitable. Many areas especially those that are located at higher elevation or at the far end of the pipe system were left unfairly without water due to low pressure and low flow velocity.

\subsubsection{Customer Complaints}

According to WSP Africa (2009), it is not appropriate to classify utilities into best and worst performing groups based on these values because a desirable level of complaints will ultimately depend on local cultural and social expectations. Further WSP Africa (2009) explained that it can be urged that a more useful indicator for assessing customer service is not the number of complaints per se but rather the time it takes for a utility to address the complaint. Nevertheless it is important to record and analyze the types and level of customer complaints and adopt good management practices applied by other similar utilities in handling and tracking customer complaints.

NWSC has a very effective customer care policy which is reviewed and updated from time to time. As part of that policy, Kampala Water operates a very efficient customer care service called Customer Call Service. The system assists in recording and keeping track of the customers' complaints until they are resolved. In the case of AWSD, there is no guideline that deals with customer care services and as such no data could be found related to customer complaints on timely basis. Besides, there were no any track records showing average response time to address the complaints.

\subsection{Human Resources Utilisation \& Development}

Building human and institutional capacity is the foundation of sustainable water resources management and efficient service delivery to achieve high level of performance. Improving the performance of water utilities is a process, which needs managerial capacity to design and manage the implementation and subsequent operation of the system, and technical competence of staff for installation, operation and maintenance. Public water utilities remain the leading players in the provision of water and sanitation services in most countries in Sub Saharan Africa. Since performance of these utilities can be constrained by limited technical, financial and institutional capacities, it becomes very important to assess the human resources development and capacity building as performance indicators because the efficiency of the utility is a reflection of the productivity of its staff.

The performance indicators widely used for this purpose are the staff productivity index expressed as the number of staff per thousand connections (registered customers), the personnel cost which expressed as the ratio of the labour cost to operational cost, and human resources development programme.

\subsubsection{Staff Productivity Index (Human Resources Utilization)}

The human resources utilization provides an insight on the efficiency of the utility in terms of staff productivity index which is expressed as the number of staff per thousand connections (registered customers).It relates the number of staff to the number of connections, with good performance manifested by a low staff per1000 connection ratio while a high ratio may indicate inefficient use of human resources (WSP-Africa, 2009). 
The analysis of staff productivity index for AWSD (Table 11) gave an average value of 14 which was twice the target recommended as benchmarking value by WSP Africa (2009), accordingly indicating that the water utility is over staffed and less productive. The staff productivity index for Kampala Water has shown steady improvement over the years from 8 in 2005 to 4.5 in 2011 showing acceptable productivity (NWSC, 2005) and (NWSC, 2011).

Table 11. Staff productivity index

\begin{tabular}{lccccccccc}
\hline \multicolumn{1}{c}{ Year } & 2004 & 2005 & 2006 & 2007 & 2008 & 2009 & 2010 & 2011 & 2012 \\
\hline No. of Staff & 428 & 469 & 458 & 450 & 436 & 421 & 428 & 390 & 460 \\
Connections & 27,500 & 28,300 & 29,150 & 29,900 & 31,850 & 32,855 & 34,128 & 34,128 & 34,721 \\
Staff/1000 connection & 15.6 & 16.6 & 15.7 & 15.1 & 13.7 & 12.8 & 12.5 & 11.4 & 13.2 \\
\hline
\end{tabular}

Another important parameter related to the number of staff while analysing the efficiency of a water utility is the level of education, skill and competence of the staff. Presence of well trained and skilled staff is a prerequisite for higher efficiency. The analysis of the skill \& level of training of the staff at AWSD shows that only few have the necessary qualifications and competence to take managerial or technical responsibilities. As a result, AWSD needs to invest more resources in improving the technical and managerial capacity and competence of its staff at all levels.

\subsubsection{Labour (Personnel) Cost}

Personnel costs in many water utilities in developing countries constitute a larger cost factor than usually recognised, draining resources from maintenance and other necessary operating expenses. The labour or personnel cost provides information in the amount of financial resources assigned for salaries and allowances relative to the operation cost which includes cost of consumables such as chemicals, spare parts, and cost of energy. It is expressed as the ratio of the labour cost to operational cost.

Table 12. Labour (personnel) cost

\begin{tabular}{cccccccccc}
\hline Year & 2004 & 2005 & 2006 & 2007 & 2008 & 2009 & 2010 & 2011 & 2012 \\
\hline Ratio of Salary to Operation (\%) & 14.8 & 14.4 & 17.0 & 17.4 & 17.8 & 9.6 & 10.5 & 11.8 & 13.4 \\
\hline
\end{tabular}

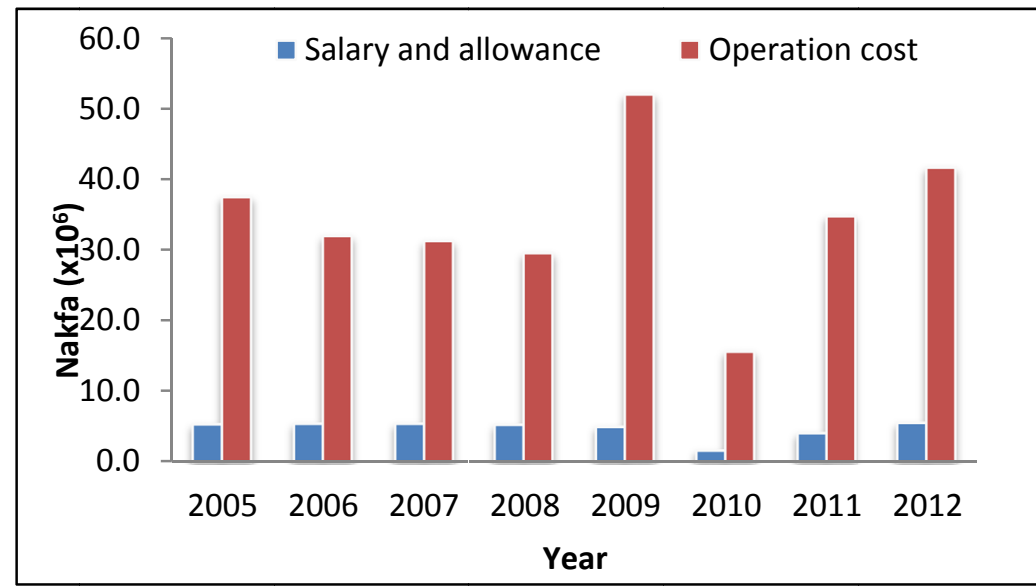

Figure 3. Water production and water billed with $40 \%$ NRW

As shown in Table 12 and Figure 3, the average labour cost in AWSD is about 15\% of the operation cost; indicating good result in terms of the budget used for salary and allowances especially when compared to that of Kampala Water which was $25.4 \%$ in 2005 and $36.1 \%$ in 2011.But this value must be analysed in conjunction with the staff productivity index (number of staff per 1000 connection) which was very high for AWSD and low 
for Kampala Water. From these analyses it could be concluded that salary scale in AWSD is lower compared to other utilities with higher labour cost and lower staff productivity index.

\subsubsection{Human Resources Development}

The WOP-Africa program considers human resource development a top priority consistent with the argument that achieving the MDGs not only requires building new infrastructure but also complementary investments in human capital. Investments in human capital include strengthening the technical and management capacity of utilities through staff training programmes. A key indicator of utility performance on human resource development is the staff training participation rate, that proportion of staff that have participated in at least one training event.

From the interview conducted with the staff and reviewing the records and documents of AWSD, it became evident that in the last 10 to 15 years there was no any kind of short term or long term training given to the staff.

\section{Conclusion}

The analysis of performance of AWSD through selected indicators and benchmarking it with Kampala Water showed that the quality of water services delivered in Asmara has been very low and that the water utility's efficiency score is very low. The findings showed how poorly the customers, in Asmara and surrounding areas, were being served and highlighted the unsustainability of the urban water services in Asmara in a context of the limited resources, increasing demand, population growth and urbanization.

The results of the analysis showed that the overall technical performance of AWSD was poor; reflected by low water production rate (40-55 l/c/d), very low water consumption $(23 \mathrm{l} / \mathrm{c} / \mathrm{d})$, high level of non-revenue water $(40 \%)$, and low service coverage (connection rate of $77 \%$ ). The actual rate of service coverage was much lower than the connection rate because being connected to the water system did not guarantee direct access to water services as a result of prolonged cut-offs and the rationing system that has been introduced since 2003. The inefficiency of the utility's water supply services were also reflected through poor financial management system and very low human resources utilization and development. These were reflected by performance indicators such as average revenue of water which was on the lower side because of high NRW and low water tariff, and staff productivity index which was very high for AWSD (around 14\%) against the target value of 7\%.

The results of this study also emphasized the urgent need of wide-ranging reforms by the decision makers in the water sector. The analysis showed that many of the performance short comings will not be remedied only through capital investment projects but also through development of effective internal performance management and monitoring systems. The research also highlighted the importance of metric and process benchmarking as a performance assessment and decision making tool for the purpose of service improvement by adopting best practices from other similar but well performing water utilities. In this case study, AWSD was benchmarked against Kampala Water which was one of the well performing utilities in the region.

The management of AWSD must apply the systematic performance analysis developed here as a tool to support their decision making process to improve technical and financial operation of the utility. For the decision support tool that was developed here, on the basis of the performance analysis, to be dynamic and instrumental in achieving the short and long term goals, AWSD is required to be transparent and introduce new customer database, improved billing and collection system, more accurate metering at all levels, and methods for accounting, monitoring and controlling NRW. The performance analysis also showed that, staff development program to be an integral part of the new management system aimed at upgrading technical skills and managerial capacity of the staff.

The methodology applied in this study could be used by water utilities in sub-Saharan Africa that are challenged by low levels of efficiency and high levels of unsatisfied customers. Before establishing any performance indicator conditions for a water utility, it is important to take into account the current condition of the system facilities to set performance levels that are feasible for system facility development and improvement. Thus an initial evaluation of the existing operation and management system of the water utility should be conducted to fully assess current capacity of the utility. One of the most important aspects to be considered in connection with the inclusion of performance indicators as conditions to the assessment of performance improvement of a water utility is to make sure that an appropriate and efficient monitoring system is in place. Performance targets will deliver the expected results only if the behaviour of the water utility can be adequately monitored and if the targets can be effectively enforced.

\section{Acknowledgments}

This research was funded by the Government of Eritrea through the National Board of Higher Education. We are grateful to the management and technical staff of Asmara Water Supply Department and NWSC of Uganda for 
allowing us access into their documents and also to collect data through field visits to the water distribution facilities and from interviewing and discussing with their key staff.

\section{References}

Ainuson, K. (2010). Urban water politics and water security in disadvantaged urban communities in Ghana. African Studies Quarterly, 11(4).

Asís, M. G. De, Leary, D. O., Ljung, P., \& Butterworth, J. (2009). Improving Transparency, Integrity , and Accountability in Water Supply and Sanitation - Action, Learning, Experiences. The World Bank. http://dx.doi.org/10.1596/978-0-8213-7892-2

Berg, S., \& Corton, M. (2007). Water utility benchmarking for managerial and policy decisions: lessons from developing countries. ... Water Association Conference on ..., (December 2007), 1-11. Retrieved from http://bear.warrington.ufl.edu/centers/purc/docs/papers/0724_Berg_Water_Utility_Benchmarking.pdf

Berg, C. Van Den, \& Danilenko, A. (2011). The IBNET Water Supply and Sanitation Performance Blue Book The International Benchmarking Network for Water and Sanitation Utilities Databook -(World Bank).

Brown, P. A. (2008). A Review of the Literature on Case Study Research. Canadian Journal for New Scholars in Education, 1(1), 1-13. Retrieved from cjnse-rcjce.synergiesprairies.ca/ojs2/index.php/cjnse/article/.../ $23 / 20$

Estache, A., \& Kouassi, E. (2002). Sector organization, governance, and the inefficiency of African water utilities. World Bank Policy Research Working Paper, (202), 1-21.

Fontanazza, C., Freni, G., \& Loggia, G. La. (2012). A composite indicator for water metre replacement in an urban distribution network, (December 2012), 37-41.

Jacobsen, M., Webster, M., \& Vairavamoorthy, K. (2013). The Future of Water in African Cities- Why Waste Water? (p. 19). doi:10.1596/978-0-8213-9721-3

Kothari, C. R. (2004). Research Methodlogy: Methods and Techniques (2nd ed., p. 397). New Delhi: New Age International (P) Ltd., Publishers Published by New Age International (P) Ltd.

Kun, O. B., Talib, S. A., \& Redzwan, G. (2007). E STABLISHMENT OF P ERFORMANCE I NDICATORS FOR W ATER. Malaysian Journal of Civil Engineering, 19(1), 73-83.

Lannier, A., \& Porcher, S. (2014). Efficiency in the public and private French water utilities: prospects for benchmarking. Applied Economics. Retrieved from http://www.tandfonline.com/doi/abs/10.1080/00036846. 2013.857002

Liemberger, R., \& Farley, M. (2004). Developing a Non-Revenue Water Reduction Strategy, Part 1: Investigating and Assessing Water Losses. Paper to IWA Congress. Retrieved from http://www.sswm.info/sites/default/files/reference_attachments/LIEMBERGER FARLEY 2004 Developing a NRW Reduction Strategy.pdf

Makaya, E., \& Hensel, O. (2014). Water Distribution Systems Efficiency Assessment Indicators-Concepts and Application. International Journal of Science and Research (IJSR), 3(7), 219-228. Retrieved from http://www.ijsr.net/archive/v3i7/MDIwMTQyNTk=.pdf

Mugisha, S., Berg, S., \& Katashaya, G. (2004). Short-term initiatives to improve water utility performance in Uganda: the case of the National Water And Sewerage Corporation. Water, 97(September 2002), 1-8. Retrieved from http://warrington.ufl.edu/centers/purc/purcdocs/papers/0423_Mugisha_Success_for_Uganda.pdf

NWSC. (2005). National Water and Sewerage Corporation of Uganda: Annual report 2004-2005. Retrieved from http://www.wateraid.org/ /media/Publications/annual-reports-and-strategies/WaterAid-uganda-annual -report-2004-2005.pdf.

NWSC. (2009). National Water and Sewerage Corporation of Uganda Corporate Plan 2009-2012: Our plan for the next 1,095 days.

NWSC. (2010). National Water and Sewerage Corporation of Uganda: Annual Report 2009-2010. Retrieved from http://www.wateraid.org/ /media/Publications/annual-reports-and-strategies/WaterAid-uganda-annual -report-2009-201.pdf. 
NWSC. (2011). National Water and Sewerage Corporation of Uganda: Annual Report 2010-2011. Retrieved from http://www.wateraid.org/ /media/Publications/annual-reports-and-strategies/WaterAid-uganda-annual -report-2010-2011.pdf

Nyaboke, J., Arasa, R., \& Ombui, K. (2013). Effects of public procurement policies on organizational performance: A case of Water Services Regulatory Board. International Journal of Social Sciences ..., 1(5), 1-14. Retrieved from http://ijsse.org/articles/ijsse_v1_i5_89_103.pdf

Parena, R., \& Smeets, E. (2001). Benchmarking initiatives in the water industry. Water Science and Technology, 44(2-3), 103-10. Retrieved from http://www.ncbi.nlm.nih.gov/pubmed/11547972

Sadiq, R., Rodríguez, M. J., \& Tesfamariam, S. (2010). Integrating indicators for performance assessment of small water utilities using ordered weighted averaging (OWA) operators. Expert Systems with Applications, 37(7), 4881-4891. doi:10.1016/j.eswa.2009.12.027

Schouten, M., \& Buyi, T. (2010). 100-days rapid change initiatives in African public water utilities. International Journal of Public Sector Management, 23(5), 431-443. doi:10.1108/09513551011058466

Schwartz, K. (2006). public water utilities: An assessment of bureaucratic and new public management models in the water supply and sanitation sectors in low-and middle-income. Retrieved from http://repub.eur.nl/ $\mathrm{pub} / 8052$

Shen, L.-Y., Jorge Ochoa, J., Shah, M. N., \& Zhang, X. (2011). The application of urban sustainability indicators - A comparison between various practices. Habitat International, 35(1), 17-29. http://dx.doi.org/10.1016/ j.habitatint.2010.03.006

UNICEF/WHO. (2011). Drinking water equity, safety and sustainability.

Vaziri, M., \& Tolouei, R. (2010). Urban water resources sustainable development: a global comparative appraisal. Iranian Journal of Science \& Technology, ..., 7.

Vishwakarma, A., \& Kulshrestha, M. (2010). Cost efficiency evaluation and performance assessment of urban water supply utilities in the state of Madhya Pradesh, India. International Journal of Civil and ..., 1(2), 234-244. doi:10.6088/ijcser.00202010019

WSP-Africa. (2009). Water Operators Partnerships- Africa Utility Performance Assessment (Final Report 2009).

Wyatt, A. (2010). Non-Revenue Water: Financial Model for Optimal Management in Developing Countries, (June). doi:10.3768/rtipress.2010.mr.0018.1006

Yin, R. K. (1984). CASE STUDY RESEARCH Design and Methods. Applied Social Research Methods Series, 5. Retrieved from faculty.washington.edu/swhiting/pols502/Yin.pdf

Zeraebruk, K., Mayabi, A., Gathenya, J., \& Zemenfes, T. (2014). Assessment of Level and Quality of Water Supply Service Delivery for Development of Decision Support Tools: Case Study Asmara Water Supply. International Journal of Sciences: Basic and Applied Research (IJSBAR), 14(1), 93-107.

\section{Copyrights}

Copyright for this article is retained by the author(s), with first publication rights granted to the journal.

This is an open-access article distributed under the terms and conditions of the Creative Commons Attribution license (http://creativecommons.org/licenses/by/3.0/). 